\title{
USO DE TANINOS HIDROLISÁVEIS PARA PRECIPITAÇÃO DE PROTEÍNAS PLASMÁTICAS
}

\author{
$\underline{\text { R.V.S. SOBRAL }}^{1}$, J.M. NASCIMENTO ${ }^{1}$, A.C.L. LEITE ${ }^{1}$ \\ ${ }^{1}$ Universidade Federal de Pernambuco, Centro de Ciências da Saúde, Departamento de \\ Ciências Farmacêuticas \\ E-mail para contato: renata.sobra1002@gmail.com
}

\begin{abstract}
RESUMO - Os taninos são compostos fenólicos, extraídos de plantas, que possuem a habilidade de formar complexos insolúveis em água com proteínas. Esse estudo visa desenvolver um novo método de precipitação de proteínas plasmáticas utilizando taninos hidrolisáveis (ácidos gálico e tânico) a partir do plasma humano. Para a precipitação, o plasma foi descongelado e centrifugado para separação do crioprecipitado. O sobrenadante obtido teve o pH ajustado (antes ou após a adição dos taninos) para diferentes valores e os taninos foram adicionados em diferentes concentrações, sob homogeneização com variações de tempo. Após a separação do precipitado por centrifugação, o sobrenadante sofreu uma segunda precipitação. As pastas brutas obtidas foram analisadas por eletroforese utilizando gel de poliacrilamida sem SDS (PAGE nativo). Nestas pastas, foi observada a predominância de 3 bandas: gamaglobulina, alfa2globulina e albumina. A presença de bandas fora dos pontos isoelétricos das proteínas mostra que o $\mathrm{pH} d a$ solução não é uma condição determinante para a precipitação. Em relação a concentração, foi definido que a melhor concentração para ambos os taninos foi $1,5 \%$ em relação ao volume do plasma. Para o tempo de homogeneização, cada tanino apresenta um perfil diferente. Diante dos resultados obtidos, concluímos que os taninos são ótimos candidatos à precipitantes de proteínas plasmáticas, mas que vários fatores influenciam na precipitação, tais como $\mathrm{pH}$, concentração e tempo de homogeneização.
\end{abstract}

Palavras-chave: Ácido Gálico, Ácido Tânico, Plasma.

ABSTRACT - Tannins are phenolic compounds extracted from plants that have the ability to form water insoluble complexes with proteins. This study aims to develop a new method of precipitation of plasma proteins using hydrolysable tannins (gallic and tannic acid) from human plasma. For a precipitation, the plasma is thawed and centrifuged to separate the cryoprecipitate. The supernatant obtained with the adjusted $\mathrm{pH}$ value (before or after an addition of the tannins) for different values and the tannins were added at different concentrations, under homogenization with time variations. After separation of the precipitate by centrifugation, the supernatant underwent a second precipitation. The slides are analyzed by electrophoresis using SDS-free polyacrylamide gel (native PAGE). In these pulps, a predominance of 3 bands was observed: gammaglobulin, alpha2-globulin and albumin. The presence of bands for the isoelectric points of the proteins shows that the $\mathrm{pH}$ of the solution is not a determining condition for precipitation. In relation to the concentration, it was defined that the best concentration for both tannins was $1.5 \%$ in relation to the volume of the plasma. For the homogenization time, each 
tannin presents a different profile. In view of the results obtained, we conclude that tannins are excellent candidates for plasma protein precipitants, but that several factors influence precipitation, such as $\mathrm{pH}$, concentration and time of homogenization.

Keywords: gallic acid, tannic acid, plasma.

\section{INTRODUÇÃ̃O}

Hemoderivados são medicamentos biológicos obtidos a partir do fracionamento industrial do plasma humano (ANVISA, 2000). Mais de 20 proteínas podem ser extraídas do plasma para fins terapêuticos, entre elas a Albumina, Imunoglobulina G, Fatores VIII e IX da Coagulação, Fator de von Willebrand, e Complexo Protombínico (Burnouf, 2007).

A precipitação de proteínas plasmáticas dar-se quase que por unanimidade a partir do método descrito por Edwin Conh, que desenvolveu um método de produção albumina a partir do plasma humano (Cohn et al., 1946). A metodologia desenvolvida por Cohn baseia-se na mudança de solubilidade das frações proteicas (precipitação de proteínas), por meio de ajuste do $\mathrm{pH}$, temperatura, força iônica e concentração de álcool (Burnouf, 2012). No entanto, a utilização de etanol provoca parcial desnaturação das proteínas levando a formação de agregados, os quais precisam ser eliminados.

Por outro lado, os taninos são compostos fenólicos, extraídos de plantas, que possuem a habilidade de formar complexos insolúveis em água com proteínas (Monteiro et al., 2005). Estes compostos podem ser encontrados em diferentes plantas, podendo estar na forma livre (como exemplo, o ácido gálico) ou agrupados (como exemplo, o ácido tânico, o qual é composto por várias moléculas de ácido gálico) (Chun et al., 1998; MelloSantos, 2001).

Diante do exposto, este estudo visa desenvolver um novo método de precipitação de proteínas plasmáticas utilizando taninos hidrolisáveis (ácidos gálico e tânico) como precipitantes, a partir do plasma humano.

\section{MATERIAIS E MÉTODOS}

O plasma utilizado em toda a pesquisa foi cedido pela Fundação HEMOPE. O plasma fresco congelado foi descongelado a $4^{\circ} \mathrm{C}$ e em seguida clarificado por centrifugação a $3.500 \mathrm{rpm}$, em $8^{\circ} \mathrm{C}$, por 10 minutos. $\mathrm{O}$ crioprecipitado obtido foi descartado e o sobrenadante foi utilizado para precipitação em duas etapas utilizando diferentes condições (ordem de ajuste do $\mathrm{pH}$, concentração dos taninos e tempo de homogeneização). Na primeira etapa, o $\mathrm{pH}$ do sobrenadante foi ajustado para 4,9 e na segunda, para 6,9, sendo estes os pontos isoelétricos (pI) das proteínas mais abundantes do plasma, a albumina e a $\mathrm{IgG}$, respectivamente. $\mathrm{O}$ ajuste do $\mathrm{pH}$ foi realizado em diferentes momentos: antes ou depois da adição dos taninos. Os taninos utilizados foram o ácido gálico ou ácido tânico, em diferentes concentrações $(0,5 \%, 1,25 \%, 1,5 \%, 2,5 \%$ e $3,75 \%$ ) e sob diferentes tempos de homogeneização (5', 10', 15' e 30'). Após homogeneização lenta, o precipitado foi separado por centrifugação nas duas etapas. A pasta bruta obtida foi analisada por eletroforese utilizando gel de poliacrilamida sem SDS (PAGE nativo). 


\section{RESULTADOS E DISCUSSÃO}

As diferentes metodologias resultaram em pastas brutas distintas, as quais variaram em cor e textura, dependendo do tanino utilizado. Nas pastas brutas obtidas a partir dos dois taninos, tivemos predominância de 3 bandas: a gamaglobulina, a alfa2globulina e a albumina.

A precipitação de proteínas através de taninos é influenciada por vários fatores, tais como: estrutura das proteínas e dos taninos, concentração, $\mathrm{pH}$, força iônica e solvente (HAGERMAN et al., 1998). Neste trabalho, os experimentos foram realizados com variações de concentrações de taninos, tempo de homogeneização após a adição dos taninos e ordem de ajuste do $\mathrm{pH}$.

As concentrações utilizadas foram: $0,5 \%, 1,25 \%, 1,5 \%, 2,5 \%$ e 3,75\%. Estas concentrações foram calculadas em relação ao volume de plasma utilizado (p/v). Para o ácido tânico, a partir da concentração de $1,25 \%$ podemos observar que as duas precipitações são suficientes para precipitar a maioria das proteínas séricas. Para o ácido gálico, a concentração ideal é a partir de 1,5\% de tanino em relação ao volume de plasma. Desta forma, achamos melhor padronizar a concentração de 1,5\% como a melhor para os dois tipos de taninos. Valores maiores de concentração tendem a precipitar tudo na primeira precipitação.

Em relação ao tempo de precipitação foram utilizados 5, 10, 15 e 30 minutos. Nos experimentos com o ácido tânico foi possível observar que o tempo não influência significantemente na precipitação, podendo esta ocorrer no tempo de 5 minutos. (HAGERMAN et al. 1998) estudaram a interação entre a BSA e dois taninos (EC16-C e PGG), variando o tempo de homogeneização entre 5 a 60 minutos, e também viram precipitação da BSA ocorreu rapidamente, com a quantidade de proteína precipitada independente do tempo. Nos experimentos com o ácido gálico, por sua vez, foi possível observar que os experimentos com duração de 30 minutos de precipitação apresentaram melhores resultados.

Em relação ao ajuste do $\mathrm{pH}$, foi utilizado os $\mathrm{pI}$ das proteínas mais abundantes no plasma, com o intuito de precipitar apenas a albumina e a IgG na primeira e segunda etapa de precipitação, respectivamente. No entanto, foi visto através do PAGE nativo que outras proteínas foram precipitadas além daquelas dos pI utilizados. De acordo com a literatura, a precipitação por taninos é $\mathrm{pH}$-sensível, ocorrendo a precipitação de forma mais eficiente em torno do ponto isoelétrico das proteínas, no entanto, pode ocorrer a precipitação de outras proteínas por interações hidrofóbicas (NACZK et al., 2001, HATANO et al., 2003; ADAMCZYK et al., 2012).

Em relação à ordem do ajuste do $\mathrm{pH}$, para o ácido tânico, a adição do tanino antes ou depois do ajuste não resulta numa alteração considerável do $\mathrm{pH}$ do plasma, já a adição do ácido gálico induz a uma redução brusca do $\mathrm{pH}$ do plasma. Desta forma, se o intuito da precipitação for precipitar as proteínas próximas ao seu pI é necessário fazer o ajuste do $\mathrm{pH}$ após adicionar o tanino.

\section{CONCLUSÃO}

O uso de taninos é bastante explorado na indústria, principalmente, na alimentícia, como exemplo, na produção de vinho. Para entender como ocorre a interação taninoproteína, muitos estudos são realizados utilizando a proteína isolada BSA (albumina sérica bovina). Esta é primeira vez que os taninos foram utilizados como precipitantes de 
proteínas diretamente do plasma humano. Foi visto que vários fatores influenciam na precipitação, tais como $\mathrm{pH}$, ordem de ajuste deste $\mathrm{pH}$, concentração e tempo de precipitação. Através dos géis de PAGE nativo, foi observado que a precipitação utilizando os dois taninos pode ocorrer mesmo fora do ponto isoelétrico das proteínas, sugerindo que provavelmente a interação tanino-proteína se dê por interações hidrofóbicas, além das ligações de hidrogênio. Por fim, após a realização de todos os experimentos foi possível verificar que o ácido tânico é um melhor precipitante quando comparado ao ácido gálico, podendo ser utilizado nas seguintes condições: concentração de $1,5 \%$, tempo de precipitação a partir de 5 minutos e ajuste de $\mathrm{pH}$ depois da adição do tanino.

\section{REFERENCIAS}

ADAMCZYK, B.; SALMINEN, J.; SMOLANDER, A.; KITUNEN, V. Precipitation of proteins by tannins: effects of concentration, protein/tannin ratio and $\mathrm{Ph}$. Internat. $\mathbf{J}$. Food Sci. Techn. 47, p.875-878, 2012.

ANVISA - Agência Nacional de Vigilância Sanitária. Resolução-RDC 46, de 18 de Maio de 2000 (DOU 19/05/00) - Normatiza os processos de produção e controle de qualidade, a aquisição e distribuição dos medicamentos hemoderivados para uso humano. Disponível: http://www.anvisa.gov.br. Acesso:8/09/15.

BURNOUF T. Modern Plasma Fractionation. Transfusion Medicine Reviews 21(2), p. 101-117, 2007.

BURNOUF T. Plasma fractionation. ISBT Science Series 7(1), p. 62-67, 2012.

CHUNG, K.; WONG, T.Y.; WEI, C.; HUANG, Y.; LIN, Y. Tannins and human health: a review. Crit. Rev. Food Sci. Nutrition38, p. 421-464, 1998.

COHN, E.J., STRONG, L.E., HUGHES Jr., W.L., MULFORD, D.J., ASHWORTH, J. N., MELIN, M., TAYLOR, H.L. Preparation and properties of sérum plasma proteins: a system for the separation into fraction of the protein and lipoprotein componentes of biological tissues and fluids. J. Am. Chem. Soc., Columbus 68, p. 459-475, 1946.

FARIA, R.A.D.D.; BATISTA, M.L.; HENEINE, L.G.D. Purificação e caracterização de subtipos slow-moving e fast-moving de imunoglobulina $\mathrm{G}$ a partir de soro de coelho. E-xacta 6 (2), p. 55 60, 2013.

HAGERMAN, A.E.; RICE, M.E.; RITCHARD, N.T. Mechanisms of protein precipitation for two tannins, pentagalloyl glucose and epicatechin(16) (4 -> 8) catechin (procyanidin)" Journal of Agricultural and Food Chemistry46 (7): 2590-2595, 1998.

HATANO, T.; HORI, M.; HEMINGWAY, R.; YOSHIDA, T. Size exclusion chromatographic analysis of polyphenol -serum albumin complexes. Phytochemistry 63 (7), p. 817 -823, 2003.

NACZK, M.; AMAROWICZ, R.; ZADERNOWSKI, R.; SHAHIDI, F. Protein precipitating capacity of condensed tannins of beach pea, canola hulls, evening primrose and faba bean. FoodChemistry 73(4), p. 467-471, 2001.

\section{AGRADECIMENTOS}

À FACEPE. 